\title{
The Grotesque Museum in Dickens' Great Expectations
}

\author{
Ehsan Hafezikermani \\ Payam-Noor University of Amol, Iran \\ Roshanak Fazli \\ Payam-Noor University of Amol, Iran
}

\section{Introduction}

This novel is Dickens' thirteenth novel and was first printed in the weekly magazine All The Year Round in 1860 (GE Introduction, v). Every chapter, from the figure of the bizarre criminal in the first chapter to the uncertainties in the last section, adds to the splendidly figurative structure of the book. Dickens in a letter to his friend, John Forster, highlighted one feature. He described the " pivot on which the story will turn" as a "grotesque tragicomic concept" (Forster 567). In this novel Dickens, from the first, has put Pip as the narrator to show everything in Pip's eyes. The grotesquery notions are associated with what Pip is trying to show by different sentences.

The main idea of the grotesquery in this novel can be interrelated to the Dickens' power of vision especially expressionistic which he as a writer recorded their effects on the narrator. Each image can have different functions in the novel, and at the end they can be linked to the central ideas or themes of the novel.

In this book, grotesquery elements are separated into three parts including characters, environment, and situations. The researcher tries to show the grotesquery images, concepts and then he will show their relations with the ideas Dickens had about the functions of these images. 


\section{A. Characters}

The grotesque pictures, every so often, have been related with caricature. Clayborough has tried to show a number of Dickens's characters containing caricature features are grotesque (Thomson 39). Caricature may be defined as the comical overstatement of characteristic or odd features. One can laugh at a caricature because of its humorous inaccurate features of a classic or well-known person or its irregularity, and he can have the same dealing to the grotesquery portrayals of a character.

In Great Expectations, a lot of characters are included, but some of them, are stated in this part which seem to have the sturdiest features of grotesque. Although most of the characters have some concepts of grotesquery in their hidden side, some of them have more vivid features as Pip, Miss Havisham, and Magwitch.

Great Expectations is a Bildungsroman, and is comprised of an indication which how a young person maybe altered and developed in a punishing culture. The commanding circumstances, which Pip has been rising up in, have several effects on his lifespan and mind. Pip described different sorts of grotesquery according to his progressive mind. Since his childhood, he confronted dissimilar conditions and characters as Magwitch and Havisham to adulthood which he recounted the things by his transformed mind.

In the first part of the novel he faces with a convict, Magwitch. His description of Magwitch is very imaginative and grotesque:

A fearful man, all in coarse gray, with a great iron on his leg, A man with no hat, and with broken shoes... a man who had been soaked in water, and smothered in mud, and lamed by stones, and cut by flints, and stung by nettles, and torn by briars... and whose teeth chattered in his head as he seized me by the chin $(G E, 3-4)$

This description by Pip is categorized as caricature because the comic and terrifying are as follow: 'broken shoes', 'torn by briars', and 'teeth chattered' in his head are some exponents forming a horrific picture of a man. "The mixture of the comic and the terrifying may be disproportionate so that we have a case of a basically comic text with a very slight element of the frightening, or vice versa." 
(Thomson 21). So it can be concluded from these sentences that as Dyson mentions "Pip is naturally less reticent with his reader, yet these have sometimes condemned him in close accord with his childhood fear" (228), grotesquery is a tool here to show fears of a child more touchable for the reader.

Pip also perceives Miss Havisham as a grotesque picture. When he meets Miss Havisham for the first time he styles her all in white which seemed to be like a skeleton:

She was dressed in ...white. Her shoes were white and she had a long white veil ... she had flowers in her hair but her hair was white .... she had not quite finished dressing, for she had one shoe on...I saw that the dress had been put upon the rounded figure young woman ...had shrunk to skin and bone...now waxwork and skeleton seemed to have dark eyes ...liked at me. $(G E, 46-8)$

The element of grotesque is 'abnormality'. According to Wolfgang Kayser in his book The Grotesque in Art and Literature, the human bodies turn to puppets, dolls and their faces frozen in masks. Also Phillip Thomson points to the word abnormality as "the experience of amusement and disgust, laughter and horror, mirth and revulsion, simultaneously, is partly at least a reaction to the highly abnormal." (24) Roger D. Sell used an idea by Raphael Linda which is included as:

The characterization of Miss Havisham provides a model of the power of repressive forces, especially in their dual roles as agents of society at large acting on the individual and as internalized matter directing one to govern the conduct of self and others according to unstated principles (218).

Fielding also has stated that Miss Havisham set herself to have revenge on the world, and only brings a new misery on herself.

As Robin Gilmour in the book The Victorian Period: The Intellectual and Cultural Context of English Literature stated that what is obvious is Dickens has chosen a character like Miss Havisham for a specific purpose, the idea of spinsters in society or Married Woman Act. In some aspects of her life, like her wealth and power, Miss Havisham shows the standards put for a spinster by society. Yet, 
because of her wealth, Miss Havisham's economic and social condition is elevated more than that of a usual middle-class spinster. It is this high rank which provides her with the extra respect and power she has as a spinster or old maid, not a simple manner of self-confidence or of complete ignorance of society's standards. Taking this into consideration, Miss Havisham supports the characteristics of spinsters and old maids more than she shows them. Her extra characteristics such as being outcast from society and her uncommon look only reinforce these criterions. Dickens makes her character believable by allowing her to do both, within these given conditions, but his picture of her offers a realistic picture of spinsterhood and old maid living in accordance with the features of these women in his time.

\section{B. Environment}

One of the sides of the grotesquery is the portrayal of the surroundings which can be classified as the notion of Gothic. Wolfgang Kayser makes two precise explanations for the grotesque in his book. He remarks that grotesque is "the estranged world" and also "an attempt to invoke and subdue the demonic aspects of the world." $(184,188)$. Dickens has used the idea of gothic grotesque to show the sundry types of Pip's account throughout his childhood to adulthood by recounting some places as Marsh, Miss Havisham's house. In Great Expectations, the marsh landscape has different significances. One aspect of marsh landscape is its ambiguity:

The marshes were just a long black horizontal line then, as I stopped to look after him, and the river was just another horizontal line, not nearly so board, nor yet so black; and the sky was just a row of long angry red lines and dense black lines intermixed. $(G E, 6)$

Here the march, the river, and also the colors are mingled, and the total image is like a portrait, very complicated and everything is being fused with other things: river with the horizon and the sky with red and black lines. In chapter three Pip explains the marsh as follows:

The mist was heavier yet when I got out upon the marshes, so that instead of my running at everything, everything seemed to run at me...the gates and dykes and banks came bursting at me through the mist...the cattle came upon me 
with like suddenness...one black ox, with a white cravat on... $(G E, 14)$

This image of the marsh expresses the ineptness of life. Dickens has used Pip's vision to show different nonliving things animated, and has showed a caricature form of animals under the shadow of human appearances as having cravat which can be considered as caricature grotesque. But if the reader reads through the novel, he may find out Pip has dissimilar thinking on the marsh. The sense of a gloomy life was made-up by Pip in this scene:

I remember that at a later period of my time," I used to stand about the church yard on Sunday evening, When night was falling, comparing my own perspective with the windy marsh view... and how on both there came an unknown way and a dark mist and then the sea. $(G E, 88)$

Later, he changed the scene into a smoother picture in which Estella and Miss Havisham are mixed with what is available to his vision: "When we passed the village and the church and the church yard, and began to see the sails of the ships as they sailed on, I began to combine Miss Havisham and Estella with the prospect" ( $G E, 105)$. The element of grotesque is associating with contraries: human with nature, these both are combined in Pip's vision.

In chapter twenty, Pip is listening to two convicts talking together. The idea of the marsh is ugly and very small as follows: "a most beastly place. Mud bank, mist, swamp and work; work, swamp, mist and mud bank" $(G E, 189)$

Most of the grotesquery components of the marsh landscape are the means of satirizing. As Thomson mentions satire aims at two reactions from the audiences: laughter, and anger or disgust but grotesquery aims to produce those reactions in confusing modes as Dickens has used them. He continues for the grotesque writers as: "the grotesque writer would present ludicrous smallness and gross evil as being one, indistinguishable, and strive for a reaction in which laughter and anger figure simultaneously and with equal force."(42)

Miss Havisham's house is another grotesquery description. The description of Pip is like old castles that are deserted for a long time. According to Kayser, one of the aspects of grotesque is panic plus eccentricity and perception of the comic. When Pip went there for the first time, he describes her house as follows: 
Within a quarter of an hour we came to Miss Havisham's house, which was of old brick, and dismal, and had agreed many iron bars to it. Some windows had been walled up; of those that remained, all the lower were rustily barred. There was a courtyard in front, and that was bared, so, we had to wait...to open the gate... $(G E, 44)$

Again Pip tries to explain that house in more direct forms of a deserted house. Like old castles which are the elements of gothic grotesque:

To be sure it was a deserted place, down to the pigeon-house in the brewery-yard, which had been blown crooked on its pole by some high wind, and would have made the pigeons think themselves at sea...but, there were no pigeons in the dove-cot, no horse in the stable, no pigs in the sty, no malt in the store house, no smells of grains and beer in the copper or the vat....in a by-yard, there was a wilderness of empty casks, which had a certain sour remembrance of better days lingering about them;... in this respect I remember those recluses as being like most others. $(G E, 52)$

The atmosphere and depiction of the house are as if the house is desolate and decomposed for a long time. Being no animal in the house, the smell of grains and beer left for a long time, and empty casks recalling the narrator about the better days are the elements of a deserted house. Harvey Peter mentions "the neglect and decay of Satis House is a parallel to the physical decay of its mistress, while both forms of disintegration are outward manifestations of her emotional decay" (184).

Pip narrates Bernard's Inn in a very odd form which the reader may mix the reactions of hilarity and dismay, so it is a kind of grotesquery description:

We entered this haven through a wicket gate, and were disgorged by in introductory passage into a melancholy little square that look to me like a flat burying-ground. ... it had the most dismal trees in it ...dismal sparrows...dismal cats... dismal house...I thought the windows of the sets of chambers into these houses were divided, were in every stage of dilapidated blind and curtain, crippled flower pot, 
cracked glass, dusty decay, ...A frouzy mourning of soot and smoke attired this forlorn creation of Bernard...(GE, 140)

Peter adds this dismal picture of Bernard's Inn not only makes Pip's disappointment at his first meeting in London more effective but it also fore shadows the frustration of Pip's great expectations . The descriptions are like a flat burying-ground, dismal trees and sparrows and dusty decay all of them are like a broken house brings the taste of death to the reader.

As a final point, Pip's first and second apartments are not far from the Thames River, which is also a place of business. When Pip and his friends are struggling to help Magwitch to escape, it is packed with "barges, sailing colliers, and coastingtraders" $(G E, 358)$. However, it is also a place of danger. As the tide decreases it leaves behind:

a little squat shoal-lighthouse on open piles, stood crippled in the mud on stilts and crutches; and slimy stakes stuck out of the mud, and slimy stones stuck out of the mud, and red landmarks and tidemark stuck out of the mud, and an old landing-stage and an old roofless building slipped into the mud, and all about us was stagnation and mud $(G E, 361)$

The river is filled with material and stagnation. The economic struggle has been stopped and left to decay and expire, caught in the mud. Just as Pip's economic struggle dies in the river with arresting and death of Magwitch. The elements of grotesque are the comic and terrifying. Everything in the mud is hilarious and in the depth is very dismaying for the Pip. It seems everything has got stuck in its clogged situation.

\section{Situations}

Roger D. Sell discusses physical clumsiness and differences between a working class and a gentleman are much highlighted in this novel. He mentions completely about becoming a gentleman by Pip:

Pip wants to become a gentleman because he wants to become a gentleman to escape from the brutality and intimidation that characterize life on the marsh. But 
gentleman in the nineteen century world involves exclusion and repression for someone like Pip, alienation from Joe and the warmth of instinctive life which the blazing forge symbolizes. (119)

It is the marked result of the treatment of convicts in the Victorian society [Great numbers on their backs, as if they were street doors]. Although, here the grotesquery element is mocking or playful grotesque, in its depth meaning the taste of satirizing the rules of the society is noticeable. Dickens according to Phillip Collins had strong and conflicting feelings about criminals (1), which it explains why he has been known to refer to criminals as both "irreclaimable wretches" and "creatures of neglect" (33). The writer challenges toward crime forms the fact that Dickens has been torn between his childhood memories of prison and poverty and the official training he has received as an adult. As Robert Coles in "Charles Dickens and Crime" mentions:

Dickens knew how hard-pressed life was for thousands of English families in mid-nineteenth century England, and he knew the legal side of such desperation--a jungle of suspicion and fear and hate. He was especially attentive [if] . . . hungry, jobless men, women, children with few if any prospects became reduced to a fate not only marginal with respect to its "socioeconomic" character but also with respect to its very humanity. (575)

Collins states Dickens has been interested in Magwitch, and wanted us to share Pip's later friendliness for him, after the terror and horror he had earlier. On the surface, the way in which Pip firstly describes Magwitch is that of an animal is a wild beast. Dickens sees Magwitch as a victim of society's problems, forced to carry the trouble of poverty on his shoulders. Dickens wants readers to believe that Magwitch has little to do with his criminal existence, and should then not be blamed. This does not seem usual with Dickens' harsher real-life attitudes toward criminals, which mainly suggest criminals have no good qualities and should be punished to the maximum level of the law.

By the novel's end, Pip has a reason to see Magwitch in a way he never would have expected, based on his first notion of the growling "fearful man." As Magwitch lies on his deathbed, Pip recalls: 
For now my repugnance of him had all melted away and in the hunted, wounded shackled creature who held my hand in his, I only saw a man who had meant to be my benefactor, and who had felt affectionately, gratefully, and generously, towards me with great constancy through a series of years. I only saw in him much better man that I had been to Joe. $(G E, 406)$

Pip can now see under Magwitch's unpleasant face a man of good heart and kindness. In fact, Pip sees himself as a worse person than Magwitch that this factor strengthens the argument that Dickens is making against judging a person on first impressions. Here the concept of tragicomic is flashing in the mind of the reader that puts him in a dangling situation to these sentences, whether laughing or minding the problem of misunderstanding. The mixing of feelings, joy and sorrow, is the function of grotesque in this part.

O'Gorman in his book The Victorian Novel mentions that Dickens has offered a gallery of portraits of wounded manners who continue their self-worth by dwelling in the past (their ancestors) (49).

\section{Conclusion}

According to Brian Cheadle in the book The Cambridge Companion to Charles Dickens 'the key notes of the novel is the Pip's intuition of life as a universal struggle, their arena increasingly London, the site of modernity" (78).

Dickens tries to show wealth and position are corrupting by grotesquery. He put different images in the Pip's mind in different situations. These images are changeable through the novel due to Pip's feeling and visions. They are sometimes terrifying or fine, sometimes terrible and shockingly or smooth and convenient. These modes are reached by grotesquery and its concepts as tragicomic, gothic.

A. H. Gomme states Great Expectations is Dickens's best-plotted novel and also is the only novel which is told completely in the first person. The questions of judgment and the law are at the center of the novel. "What would a just judgment be on Estella, Magwitch, Miss Havisham or indeed Pip himself?" (GE Introduction, xiii) Dickens himself is like a judge through the story and by using 
different descriptions puts some sentences on his characters and scenes as they are mentioned through grotesquery.

The idea of Dickens on this novel is written by him in a letter to Forster describing his art of depicting and writing: "I have put in as pretty a little piece of writing as I could" (Forster 289). The reader may understand that all the plot structure and style and characters are directly connected to the development of Pip which is the central character of this novel.

At the end, this novel is in the form of a painting. The art of Dickens in the descriptions and characterizations are recognizable. The form of descriptions in the gothic form and the art of the caricature insertion of character's appearances are the highlighted points of the novel that through grotesquery he shows them. Comic and tragic situations, ridiculing features of conversations and the humorous aspects of the novels, all are other noticeable features of the narratives created by grotesquery.

\section{References and Notes:}

Ackroyd, Peter. Dickens. New York: Harper, 1990.

Chesterton, G. K. Criticism and Appreciation of the works of Charles Dickens. New York: Dutton, 1911.

Clayborough, Arthur. The Grotesque in English Literature. Oxford: Clarendon Press, 1965.

Collins, Philip A. W. Dickens and Crime. New York: St. Martin's Press, 1962.

Connor, Steven. Charles Dickens. Oxford: Blackwell, 1985.

Cuddon, J.A. A Dictionary of Literary Terms. New York: Penguin Press, 1984.

Daiches, David. "Charles Dickens' World". A Critical History of English Literature. New York: Roland, 1970.

Daleski, H. M. Dickens and the Art of Analogy. London: Faber and Faber Limited, 1970.

Dickens, Charles . Great Expectations. Hertfordshire: Wordsworth, 1992.

Dyson, A. E. The Inimitable Dickens. London: Macmillan Press, 1970.

Dyson, A. E. Dickens: Modern Judgment. London: Macmillan Press, 1968.

Eagleton, Terry. The English Novel. Oxford: Blackwell, 2005.

Fielding, K. J. Charles Dickens: a critical introduction. London: Longmans, 1965.

---. Charles Dickens: The Speeches. London: Billing and Sons Limited, 1988.

Forster, John. The Life of Charles Dickens. 2 Vols. London: Dent, 1966.

Gilmour, Robin. The Victorian Period: The Intellectual and Cultural Context of English Literature (1830-1890). New York: Longman,1996.

Gissing, George R. Critical Studies of the Works of Charles Dickens. New York: Greenberg, 1924.

Gomme, A.E. Dickens: Literature in Perspective Ed. Kenneth Grose. London: Evans Brothers Limited, 1971.

Gorman, Francis O. The Victorian Novel: A Concise Companion.Oxford: Blackwell, 2005. 
---. The Victorian Novel. Oxford: Blackwell, 2002.

House, Humphry. The Dickens World. London: Oxford University Press, 1961.

Jordan, John O. Charles Dickens: the Cambridge Companion. New York: Cambridge University Press, 2001.

Kayser, Wolfgang. The Grotesque in Art and Literature. Translated by Ulrich Weisstein. Bloomington: Indiana University Press, 1957.

Kincaid, James R. Dickens and the Rhetoric of Laughter. Oxford: Clarendon Press, 1971.

Lucas, John. The Melancholy Man: A study of Dickens' novels. Totowa: Barnes and Noble, 1980.

Morgan, Lee. A Handbook of Critical Approaches to Literature. New York: Harper and Row Publishers.

Pritchett, V. S. "the comic world of Dickens", The Victorian Novel:Modern Essay in Criticism. Ed. Ian Watt. New York: Oxford University Press, 1971.

Price, Martin. Dickens: A collection of critical essays. Englewood Cliffs: Prentice-Hall, 1967.

Pykett, Lee. Charles Dickens: Critical Issues. New York: Palgrave, 2002.

Sell, Roger D. Great Expectations: New Casebooks. London: Macmillan, 1994.

Sucksmith, Harvey Peters. The Narrative Art of Charles Dickens. Oxford: Clarendon, 1970.

Steig, Michael. "Defining The Grotesque: An Attempt at Synthesis", in Journal of Aesthetics and Art Criticism, summer 1970: 259-60 .

Thomson, Phillip. The Grotesque. London: Methuen Ltd, 1972.

Wall, Stephen. Charles Dickens: A Critical Anthology. England: Penguin Books Ltd., 1970. 


\title{
Summary
}

\section{The Grotesque Museum in Dickens' Great Expectations}

\author{
Ehsan Hafezikermani
}

Payam-Noor University of Amol, Iran

\section{Roshanak Fazli}

Payam-Noor University of Amol, Iran

This novel is Dickens' thirteenth novel and was first printed in the weekly magazine All The Year Round in 1860 (GE Introduction, v). It is a Bildungsroman and its characters are developing through the story. So, Dickens, from the beginning, uses Pip as his camera to display almost everything using grotesquery elements in the novel. Pip makes different mental pictures in the story about most of the things, and it shows that he is changing his mind as he is growing up. So, the idea of grotesquery is evolving too; for instance, ideas of Pip about Magwitch are changed from the opening to the end of the story.

In this book, grotesquery features are separated into three parts including characters, environment, and situations. Here, the main idea of the grotesquery can be connected to the Dickens' skills of visualization, especially expressionistic, which he as a writer detailed their effects on the narrator. Each image and notion can have different purposes in the novel, and at the end, they can be associated with the central ideas or themes of the novel.

Key Words: Charles Dickens, Grotesque, Caricature, Macabre, Gothic, Satire, Bizarre, 